\title{
NEW KEYNESIAN LIQUIDITY TRAP AND CONVENTIONAL FISCAL STANCE: AN ESTIMATED DSGE MODEL
}

\author{
Olatunji Abdul SHOBANDE ${ }^{1}$, Oladimeji Tomiwa SHODIPE ${ }^{2}$ \\ ${ }^{1}$ University of Aberdeen, Aberdeen, Scotland, UK \\ ${ }^{2}$ Eastern Illinois University, Illinois, USA \\ Corresponding author's e-mail: o.shobande.19@abdn.ac.uk
}

\begin{abstract}
The study investigates the effect of New Keynesian liquidity trap on fiscal stance in the United States, United Kingdom and Japan economies. We developed our DSGE model in the context of an optimal and persistent interactive fiscal policy, which allows us to track the transmission channel through which shocks are distributed among real economic variables. The evidence suggests that zero lower bound mitigates the ability of monetary policy to absorb the effect of exogenous shock on the macroeconomic variables while expansionary fiscal policy was able to absorb the shock persistence transmitted from the nominal interest rate.
\end{abstract}

Keywords: Fiscal Policy, Liquidity Trap, Bayesian, DSGE Model.

JEL Classification: E13; E62

\section{INTRODUCTION}

The study examines the effect of the Zero Lower Bound (ZLB) rate on conventional fiscal responses within the New Keynesian DSGE model in the United States, United Kingdom and Japan. It probes whether stimulating household consumption by manipulating the real rate of interest might trigger a negative fiscal multiplier effect on the economies. We further re-evaluate the extent to which shock spread through the interest rate transmission mechanism could be absorbed by persistent fiscal responses. To cover all objectives set, we contest the earlier assumption on the interaction of sustainable increase in the interest rate within the fiscal expansion as it influences shock transmitted through the product market to the financial sector.

The significance of this study is immense as it aims at reconciling various disputes surrounding the aggregate demand policies. First, we seek to reconcile the orthodox belief that monetary policy can serve as a remedy for inflationary control within the new Keynesian framework (Azariadis, 2018; Baxter \& King, 1993; Catalano \& Pezzolla, 2017; Gelain, Iskrev, Lansing, \& Mendicino, 2019; Patrick, Moura, \& Pierrard, 2019; Reis, 2018; Vines \& Wills, 2018). In particular, the New Keynesian mandates have shown that inflation persistence can act as antidote for growth recovery through output targeting (Blanchard, 2018; Christiano, Eichenbaum 
\& Trabandt, 2018; Cochrane, 2011; Ginters \& Buss, 2015; Mankiw \& Reis, 2018; Miyamoto, Nguyen \& Sergeyev, 2017; Shobande, 2019). Thus, the implication of neglecting conservative monetary control for unconventional fiscal policy is a major motivation behind this study.

Second, the inability of domestic monetary policy to influence the domestic financial market, and macroeconomic predictors due to the disparity in the interest rate created by unified monetary policy and the international financial market, makes it extremely difficult to control external shocks. To the best of our knowledge, the monetary instrument that can control the shocks from the exogenous factor is absent in present literature. Thus, what we are left with is to allow the alternative fiscal policy to respond to aggregate fluctuation while shocks on the system are controlled by the monetary authority. Despite this fact, zero lower bound at a nominal interest rate still have a negative impact on the fiscal multiplier as documented by some contemporary studies (Afonso \& Jalles, 2017; Ashihara \& Kameda, 2018; Boubaker, Nguyen \& Paltalidis, 2018; Cochrane, 2014, 2017; Diniz, 2018; Förster \& Hayo, 2018; Gobbi \& Grazzini, 2019; Hur \& Rhee, 2019; Kataryniuk \& Vallés, 2018; Lorenzoni \& Werning, 2013; Prota \& Grisorio, 2018; Werning, 2015). For example, a study by Cochrane (2017) has shown that there is a frictionless limit between the interest rate and fiscal multiplier. The scholar further suspects the tendency for an interest rate under rational expectation - New Keynesian framework to affect negatively the fiscal multiplier due to output variation perceived in the system (Buera \& Nicolini, 2014; Cars \& Lustenhouwer, 2017; Cochrane, 2005, 2011, 2014, 2017, 2018; Lorenzoni \& Werning, 2013; Ramey \& Zubairy, 2018; Werning, 2015).

Third, many studies that attempt to examine the relative impact of ZLB failed to account for the implication on fiscal policy. The relative few who attempted to check the policy mix reported confusing results (Barro, 1980, 1981; Barro \& Gordon, 1983; Christiano, Trabandt \& Walentin, 2011; Cochrane, 2005, 2017, 2018). For example, earlier studies claimed that fiscal expansionary crowd out private investment but stimulate output growth (Barro, 1980, 1981; Barro \& Gordon, 1983). The study by Cochrane $(2017,2018)$ established that unexpected increase in the interest rate reduces aggregate demand but with a negative effect on the fiscal multiplier. Contrariwise, some studies claimed that interaction between the fiscal multiplier at ZLB was likely to be higher than expected (Ramey, 2011), while relatively few studies claimed that the fiscal multiplier at ZLB was half due to distortionary tax income (Christiano et al., 2011; Drautzburg \& Uhlig, 2015; Roch \& Uhlig, 2018; Uhlig, 2005). Based on these discrepancies and difference in views and results, the need to further investigate the link between these variables necessitated the present study.

\section{MODEL}

In this section, we set up a DSGE model to interact with integrated policy mix with an effort to predict how economic uncertainties can be managed during the zero lower bound period. We follow earlier work by Boldrin, Christiano and Fisher (2001), Werning (2015), Drautzburg and Uhlig (2015), Cochrane (2017, 2018). 


\section{Consumption Sector}

We considered a finite number of economic agents with consumption function stated as follows:

$$
\operatorname{Max} \sum_{t=0}^{\infty} \beta^{t} u\left(C_{t} G_{t}\right)
$$

where $0<\beta<1$ is the discount factor for consumption, $C_{t}$ denotes household consumption and $G_{t}$ denotes government consumable goods (Jiang, 2019). We then assumed that the agent utility function exhibited constant elasticity of substitution (CES) represented as follows:

$$
\begin{gathered}
U=\left[\phi\left(C_{t} \xi G_{t}\right)^{\rho-1 / \rho}+(1-\phi)(1-0)^{\rho / \rho-1}\right]^{\rho / \rho-1} \\
\text { s.t } \quad C_{t}+I_{t}=r k_{t}-\tau_{t}^{k}\left(r_{t}-\delta\right) k_{t}+\left(1-\tau_{t}^{k}\right),
\end{gathered}
$$

where $k_{t}$ denotes private capital, $I_{t}$ is investment, $r_{t}$ is return on capital, $\prod t$ denotes profit, $0<\delta<1$ is depreciation on capital stock, $\tau_{t}^{k}$ is tax on household capital.

\section{Investment Sector}

We consider the firm level investment with the function below:

$$
I_{t}=\left[\int_{0}^{1} \vartheta_{t}^{I}(v)^{\psi^{I}} d v\right]^{1 / \psi^{I}-1}
$$

where the elasticity of substitution for investment becomes $1 / \psi^{I}-1$ and capital accumulation becomes:

$$
\begin{gathered}
E_{0} \sum_{t=0}^{\infty} P_{t}^{k} 1+K^{k} / 2\left(\frac{I_{t}}{I_{t-1}}\right) I_{t}-I_{t} \\
K_{t}=\sigma^{I_{t}} /_{I_{t-1}}+(1-\delta) K_{t-1},
\end{gathered}
$$

where $\sigma^{I_{t}} /_{I_{t-1}}$ denotes adjustment cost defined as follows:

$$
1-K^{k} / 2\left(\frac{I_{t}}{I_{t-1}}-1\right)^{2} I_{t}
$$

where $K^{k}$ is adjustment cost parameters.

$$
P_{t}^{I}=\left[\int_{0}^{1} p_{t}^{I}(\mathrm{v})^{\psi^{I}} / \psi^{I}-1 d v\right]^{\psi^{I}-1 / \psi^{I}}
$$




\section{Price Setting Dynamics}

We follow the price setting dynamic in the work by Calvo (1983), Clarida et al. (1998) as used by Drautzburg and Uhlig (2015), Cochrane (2018) presented as follows:

$$
P_{t}^{*}-P_{t-1}=(1-\tau v) \sum_{k=0}^{\infty}(\tau v)^{k} E_{t}\left[\left(\widetilde{m c} c_{t+k \uparrow t}+\left(P_{t+k}-P_{t-1}\right)\right],\right.
$$

where $\widetilde{m c}_{t+k \uparrow t}=\left[m c_{t+k \uparrow t}-m c\right]$ defined as deviation of marginal cost from the steady state and $m c$ denotes $\mu$, where $\mu=\log \left[\frac{\tau}{1-\tau}\right]$ defined as $\log$ of desired gross mark-up (see Benchimol, 2015).

\section{Central Bank Decision and Social Loss/Consequences}

The model of social loss function that the central banks seek to minimize is presented as follows:

$$
L_{t}^{S}=1 / 2 E_{t} \sum_{i=0}^{\infty} \beta^{i}\left(\lambda y_{t}^{2}+\pi_{t+1}^{2}\right), \quad \lambda>0
$$

Where $\lambda$ denotes weight on output gap of ambitious central banks, and social loss is subject to output gap and inflation dynamics.

Monetary policy reaction function by Cochrane $(2017,2018)$ is defined by a set of equations that signifies central bank monetary operation as follows:

$$
\begin{aligned}
y & =\sigma\left(i_{t}-\pi_{t}-\rho\right)+e_{y t} \\
\pi_{t} & =\pi_{t-1}+\vartheta y_{t}+e_{\pi t} \\
i_{t} & =r_{t}+\delta_{\pi} \pi_{t}+\phi_{y} y+e_{i t},
\end{aligned}
$$

where $\delta_{\pi}>1$ stability threshold and $\delta_{\pi}<1$ unstable.

We then applied the version of the New Keynesian Philip curve equation (Cochrane, 2017, 2018) by integrating equations (9), (10), (11), and we have

$$
\begin{gathered}
i_{t}=i+\sum_{j=1}^{n i} \psi_{i j}\left(i_{t-j}-\tilde{\imath}\right)+\sum_{j=1}^{n i} \delta_{\pi j}\left(\pi_{t-j}-\tilde{\pi}\right)+ \\
+\sum_{j=1}^{n i} \phi_{y j}\left(\tilde{y}_{t-j}\right)+e_{m t},
\end{gathered}
$$

where $e_{m t}$ is monetary policy shock, $\tilde{\pi}$ denotes deviation in inflation, $\tilde{y}$ denotes long-run output.

Following Taylor's rule, we assumed equilibrium condition for an explosive or short-tempered economy where $i_{t}=\tilde{y}=\tilde{\pi}=0$

$$
i_{t}=i_{t}^{*}+\delta_{\pi j}\left(\pi_{t}-\pi_{t}^{*}\right)+\phi_{y j}\left(y_{t}-y_{t}^{*}\right)
$$

Thus, residual combination of shocks becomes: 


$$
i_{t}=\delta_{\pi j} \pi_{t}^{*}+\phi_{y j} y_{t}^{*}+\cdots x_{t}^{*}
$$

We assumed that the central bank reaction function was based on the Taylor rule. It then follows that central bank response baseline equation is presented as:

$$
R_{t}=\left(R_{t-1}\right)^{\theta}\left[\pi_{t}^{(1+\varphi \pi)}\left(Y_{t} Y_{Y_{t-1}}\right)^{\theta_{y}} R^{s}\right]^{(1-\alpha)} e_{t}^{R},
$$

where $R_{t}$ is a nominal interest rate, $\theta_{y}$ denotes a response rate to output and $\varphi \pi$ denotes the index inflation, $R^{S}$ is an interest rate at steady state, $0 \leq \alpha \leq 1$ connected with interest rate responses to real economic variables, $e_{t}^{R}$ is shock originating from the nominal interest rate as zero average and constant variance.

\section{The Zero Lower Bond}

Drawing from the work of Drautzburg and Uhlig (2015), Shobande (2018) and Cochrane (2018), our zero lower bond equation becomes:

$$
R_{t_{E}}^{z}=1-\left(Z L B_{t}\right) R_{t}^{\gamma}+Z L B_{t} \widetilde{R_{t_{E}}^{z}},
$$

where $R_{t_{E}}^{Z}$ denotes a steady state of nominal return $(\epsilon>0), R_{t}^{\gamma}$ denotes a counterfactual level of set interest rate when ZLB is obligatory.

\section{Fiscal Policy}

The government adheres to a balanced budget rule as follows:

$$
g_{t}=T_{t}
$$

where $g_{t}=\sum_{t=1}^{\infty} g_{t} /(1+r)^{t} \quad$ and $\quad T_{t}=\sum_{t=1}^{\infty} T_{t} /(1+r)^{t}, T_{t}$ denotes government lump sum tax, and $g_{t}$ denotes government spending.

Therefore, government consumption is represented as follows:

$$
\begin{gathered}
\operatorname{Max}_{0}\left(\sum_{t=0}^{\infty} \beta^{t} u\left(C_{t}, b_{g_{t+1}} / R_{g_{t}}\right)\right. \\
\text { s.t } B_{t+1}-\left(1+r_{t}\right) B_{t}+{ }^{M_{t+1} / P_{t+1}}-{ }^{M_{t}} /_{P_{t}}+b_{g_{t+1}} / R_{g_{t}}+\int T_{t} \theta d(z),
\end{gathered}
$$

where $\int T_{t} \theta d(z)$ denotes total tax receipt, $b_{g_{t+1}}$ denotes government debt, $R_{g_{t}}$ denotes return on government bond.

\section{DATA}

In this section, we highlight briefly the sources and data used. We justified the appropriateness of the United States, United Kingdom and Japan data in our study. 
We showed the prior distributions and the calibrated parameters we used in our estimation. We further identified and presented different optimal and interactive fiscal policies' simulation scenarios.

We derived our estimation and simulation results using annual time-series data spanning from 1970 to 2018. The variables considered for this empiric analysis are inflation-adjusted private final consumption, chained 2010 capital formation, inflation measured by GDP implicit deflator index, the annualized interest rates (federal fund rate, bank of England base rate, bank of Japan discount rate), government expenditure and chained 2010 gross domestic product. We proxy bond spread from corporate 10-year bond treasury differential and the wages as hourly compensation index. We sourced our data from the World Bank - World Development Index (WDI), International Monetary Fund (IMF)-IFS, Federal Reserve of St. Louis (FRED), Bank of Japan (BoJ) statistics and EuroStat.

However, the log deviation data are converted to reflect the deviation from their steady-states using the HP procedures, except for the interest rate. We used these transformed data to estimate the log-linearized DSGE model as developed above using the Bayesian technique in Dynare.

We selected three big world economies (the United States, Japan and the United Kingdom) for investigating the relevance that we theoretically accorded to the fiscal policy in absorbing exogenous shocks in the ZLB economic atmosphere. These countries have practically suffered macroeconomic shocks from low interest rates, in which monetary stabilization tools failed to remedy; yet the practice of ZLB persists in these economies. In recent years, the fiscal policy adoption to remedy these crises (especially, Japan) motivated us to examine and recommend fiscal tools in stabilizing these economies from stochastic innovation.

As it were, we assume that the shocks from the several rounds of quantitative easing and lower interest policy adoption since the financial crisis can cause the conventional monetary policy to be useless. This calls for policy re-evaluation and coordination. Praščević \& Ješić (2019) have recently suggested an unconventional monetary policy to break the episodes of ZLB and its macroeconomic consequences. Interestingly, our paper derives economic implications from different levels of fiscal involvement in such an interest rate environment. Our simulation results (Panel 1-4) technically reveal the importance of a high interactive fiscal policy in the monetary policy stabilization goals in the USA, UK and Japan. This thus justifies the appropriateness of a rich dataset used for the current study.

\section{Bayesian Estimation}

The application of Bayesian technique is useful in our model estimation. We used the Bayesian tool in Dynare developed for MATLAB to estimate our DSGE model. We generated the posterior parameters for the optimal simulation scenario using the Markov Chain Monte Carlo (MCMC) - Metropolis-Hastings algorithm chain of 500000 in length. To estimate this model, we calibrated and used prior information from existing literature.

In the end, we achieved three aims using the Bayesian estimation for our study. First, we used Bayesian inferences to obtain different sets of interactive fiscal policy in the DSGE model that minimised the societal loss function from the constraints 
introduced by ZLB. The loss was captured by deviation of consumption, inflation and output from their steady states.

Second, we technically observed the speed of loss reduction (i.e., convergence of these macroeconomic variables to their steady states) after some stochastic innovations in the ZLB environment.

Third, we selected the optimal interactive fiscal policy DSGE and used the estimates to recommend policies.

To achieve our simulation objectives, we calibrated some prior parameters that were important for our study and used them to derive four simulation scenarios $\left(\mathrm{S}_{1}-\mathrm{S}_{4}\right)$ for forty $(40)$ periods in length. We calibrated fiscal instruments vis-à-vis the standard monetary reaction function and monetary policy that were based exclusively on inflation targeting (IT) to derive different sets of loss responses. In the first case scenario $\left(S_{1}\right)$, we allowed for one-period interactive fiscal policy with monetary policy striving to stabilise inflation and output gap. The second scenario $\left(\mathrm{S}_{2}\right)$ replicated $\mathrm{S}_{1}$ but allowed the fiscal policy to persist up to fourth periods. In the third case scenario $\left(S_{3}\right)$, we allowed the one-period fiscal policy to interact with monetary policy that targeted only inflation. The fourth case scenario $\left(\mathrm{S}_{4}\right)$ used the third scenario but we allowed the fiscal policy to persist. The calibrated output gap is the estimated policy makers' responses to output deviation from the equilibrium. This parameter is informed by the influential papers of Drautzburg and Uhlig (2015), Iwata (2009, 2013), Bhattarai and Trzeciakiewicz (2017), and Cochrane (2017, 2018). For the fiscal instruments, we estimated the share of government spending in the gross domestic products from 1970 to 2018. The average of consumption and capital tax rate for the years between 1970 and 2017 were used in the simulation scenarios. Contrary to some studies that focused on government spending, we took a broader view of fiscal policy in the stabilisation process as revealed in this work. Table 1 summarises the calibrated fiscal tools and simulation scenarios.

Table 1. Calibrated Parameters and Simulation Scenarios $\left(\mathrm{S}_{1}-\mathrm{S}_{4}\right)$

\begin{tabular}{|l|c|c|c|c|c|c|c|c|c|c|c|c|}
\hline Parameters & \multicolumn{4}{|c|}{ United States } & \multicolumn{4}{c|}{ Japan } & \multicolumn{4}{c|}{ United Kingdom } \\
\hline & $\mathrm{S}_{1}$ & $\mathrm{~S}_{2}$ & $\mathrm{~S}_{3}$ & $\mathrm{~S}_{4}$ & $\mathrm{~S}_{1}$ & $\mathrm{~S}_{2}$ & $\mathrm{~S}_{3}$ & $\mathrm{~S}_{4}$ & $\mathrm{~S}_{1}$ & $\mathrm{~S}_{2}$ & $\mathrm{~S}_{3}$ & $\mathrm{~S}_{4}$ \\
\hline Government-output ratio & 0.30 & 0.30 & 0.30 & 0.30 & 0.35 & 0.35 & 0.35 & 0.35 & 0.40 & 0.40 & 0.40 & 0.40 \\
\hline Consumption tax & 0.05 & 0.05 & 0.05 & 0.05 & 0.06 & 0.06 & 0.06 & 0.06 & 0.20 & 0.20 & 0.20 & 0.20 \\
\hline Capita tax & 0.40 & 0.40 & 0.40 & 0.40 & 0.38 & 0.38 & 0.38 & 0.38 & 0.19 & 0.19 & 0.19 & 0.19 \\
\hline Mon. rule output gap & 0.13 & 0.13 & 0 & 0 & 0.06 & 0.06 & 0 & 0 & 0.12 & 0.12 & 0 & 0 \\
\hline
\end{tabular}

Table 2 presents the prior distribution we used in the study based on the research evidence in the existing literature. We used the prior means which had beta, normal, gamma densities, and we used inverse gamma for all the standard deviation of shocks; $w_{2}, b_{2}, \rho_{2}, \varphi_{2}, g_{2}, \tau_{2}, \psi_{2}$. Except for the calibrated values which we estimated, we technically relied on the study of Iwata (2013), Drautzburg and Uhlig (2015), Bhattarai and Trzeciakiewicz (2017), Nasir, Yago, Soliman and Wu, (2016), Cochrane $(2017,2018)$ and Jump and Levine (2019), for the prior distribution. In line with these studies, we used normal distribution for risk averseness, $\rho$; monetary policy response to inflation, $m_{\pi}$; and capital share, $\alpha$; and used beta distribution for 
habit, $h$; price indexation, $I_{p}$; and wage indexation; $I_{\omega}$; calvo price, $p$; and wage, $\omega$; interest rate smoothing, $m_{p}$ in the monetary reaction function, persistence in wage mark-up, $w_{1}$; price mark-up, $\rho_{1}$; bond spread, $b_{1}$; technology, $\varphi_{1}$; government, $g_{1}$; tax shock, $\tau_{1}$; and monetary policy shock, $\psi_{1}$. We selected gamma distribution for bond spread. These prior parameters for the three economies are presented in Table 2.

Table 2. Prior Distribution

\begin{tabular}{|c|c|c|c|c|c|c|c|c|}
\hline \multirow[t]{3}{*}{ Parameters } & & \multicolumn{7}{|c|}{ Prior } \\
\hline & & \multirow[b]{2}{*}{ Density } & \multicolumn{2}{|c|}{ United States } & \multicolumn{2}{|c|}{ Japan } & \multicolumn{2}{|c|}{ United Kingdom } \\
\hline & & & Mean & Std. & Mean & Std. & Mean & Std. \\
\hline Habit & $h$ & Beta & 0.85 & 0.02 & 0.70 & 0.01 & 0.71 & 0.02 \\
\hline Risk averseness & $\rho$ & Normal & 1.17 & 0.02 & 1.13 & 0.06 & 0.95 & 0.02 \\
\hline Index price & $I_{p}$ & Beta & 0.28 & 0.07 & 0.15 & 0.03 & 0.32 & 0.09 \\
\hline Index wage & $I_{\omega}$ & Beta & 0.41 & 0.08 & 0.35 & 0.05 & 0.38 & 0.14 \\
\hline Calvo price & $p$ & Beta & 0.81 & 0.03 & 0.79 & 0.05 & 0.78 & 0.05 \\
\hline Calvo wage & $\omega$ & Beta & 0.83 & 0.03 & 0.73 & 0.04 & 0.56 & 0.05 \\
\hline Mon.rule Inflation & $m_{\pi}$ & Normal & 1.63 & 0.18 & 1.97 & 0.14 & 1.60 & 0.24 \\
\hline Mon.rule output gap & $m_{y}$ & - & sim. & sim. & sim. & sim. & sim. & sim. \\
\hline Interest smoothening & $m_{p}$ & Beta & 0.92 & 0.02 & 0.80 & 0.04 & 0.74 & 0.02 \\
\hline Capital share & $\alpha$ & Normal & 0.24 & 0.01 & 0.15 & 0.01 & 0.25 & 0.03 \\
\hline Bond spread & $\delta$ & Gamma & 0.47 & 0.04 & 0.36 & 0.02 & 0.33 & 0.01 \\
\hline AR (1) wage mark -up & $w_{1}$ & Beta & 0.97 & 0.01 & 0.94 & 0.02 & 0.96 & 0.01 \\
\hline AR (1) bond spread & $\frac{1}{b_{1}}$ & Beta & 0.91 & 0.02 & 0.67 & 0.01 & 0.93 & 0.02 \\
\hline AR (1) price mark- up & $\rho_{1}$ & Beta & 0.91 & 0.05 & 0.72 & 0.06 & 0.89 & 0.04 \\
\hline AR (1) technology & $\varphi_{1}$ & Beta & 0.95 & 0.01 & 0.89 & 0.04 & 0.93 & 0.01 \\
\hline AR (1) government & $g_{1}$ & Beta & 0.98 & 0.01 & 0.92 & 0.01 & 0.97 & 0.01 \\
\hline AR (1) tax shock & $\tau_{1}$ & Beta & 0.98 & 0.01 & 0.96 & 0.01 & 0.98 & 0.01 \\
\hline AR (1) monetary policy & $\psi_{1}$ & Beta & 0.22 & 0.05 & 0.13 & 0.02 & 0.15 & 0.02 \\
\hline Std. Dev wage mark -up & $w_{2}$ & Inv Gam. & 0.23 & 0.02 & 0.26 & 0.05 & 0.29 & 0.02 \\
\hline Std. Dev. bond spread & $b_{2}$ & Inv Gam. & 0.08 & 0 & 0.05 & 0.01 & 0.06 & 0.01 \\
\hline Std. Dev. price mark-up & $\rho_{2}$ & Inv Gam. & 0.32 & 0.02 & 0.16 & 0.01 & 0.46 & 0.05 \\
\hline Std. Dev. technology & $\varphi_{2}$ & Inv Gam. & 0.47 & 0.02 & 0.57 & 0.07 & 0.43 & 0.02 \\
\hline Std. Dev. government & $g_{2}$ & Inv Gam. & 0.36 & 0.02 & 0.38 & 0.04 & 0.67 & 0.07 \\
\hline Std. Dev. tax shock & $\tau_{2}$ & Inv Gam. & 1.44 & 0.08 & 1.32 & 0.05 & 1.61 & 0.12 \\
\hline Std. Dev. monetary rule & $\psi_{2}$ & Inv Gam. & 0.22 & 0.05 & 0.13 & 0.02 & 0.18 & 0.06 \\
\hline
\end{tabular}

\section{RESULTS}

Panels 1-4 depict the three-dimensional graphical illustrations of the dynamic responses of output, inflation and consumptions to the stochastic innovations in our model within the framework of zero lower bound interest rate. We calculated and observed the differential in the magnitudes of the losses to the central banks based on the deviation of these macroeconomic predictors from their equilibrium after stochastic shocks hit the economies. The size of the disequilibrium/loss is depicted on the $\mathrm{Y}$-axis, the convergence periods is displayed on the $\mathrm{X}$-axis and the economic predictors are captured on the Z-axis. From our estimations, we find the following:

Panel 1 (Figs. 1-3) reveals the deviation of the macroeconomic variables from the steady states in a conventional monetary policy that strive to stabilise the output gap and inflation with minimal fiscal policy intervention. We found that the US 
consumption, inflation and output deviated from the steady states by $15 \%, 9 \%$ and $12 \%$, respectively, as initial responses to shocks in the ZLB environment and subsequently converged to the equilibrium after some periods. The Japanese macroeconomic variables, which initially responded by $17 \%, 13.9 \%$ and $14.3 \%$, dropped while the UK recorded losses of $12.9 \%, 8 \%$ and $10.2 \%$ to macroeconomic predictors from shocks. The magnitude of these losses justifies the monetary policy impotency to absorb the exogenous shocks when fiscal involvement is negligible. We observed that the conventional monetary policy was incapacitated by the presence of the ZLB and central banks' struggle to minimise the manifestation of the shocks on these macroeconomic predictors.

Panel 1. Standard Monetary and Low Fiscal Policy Interaction
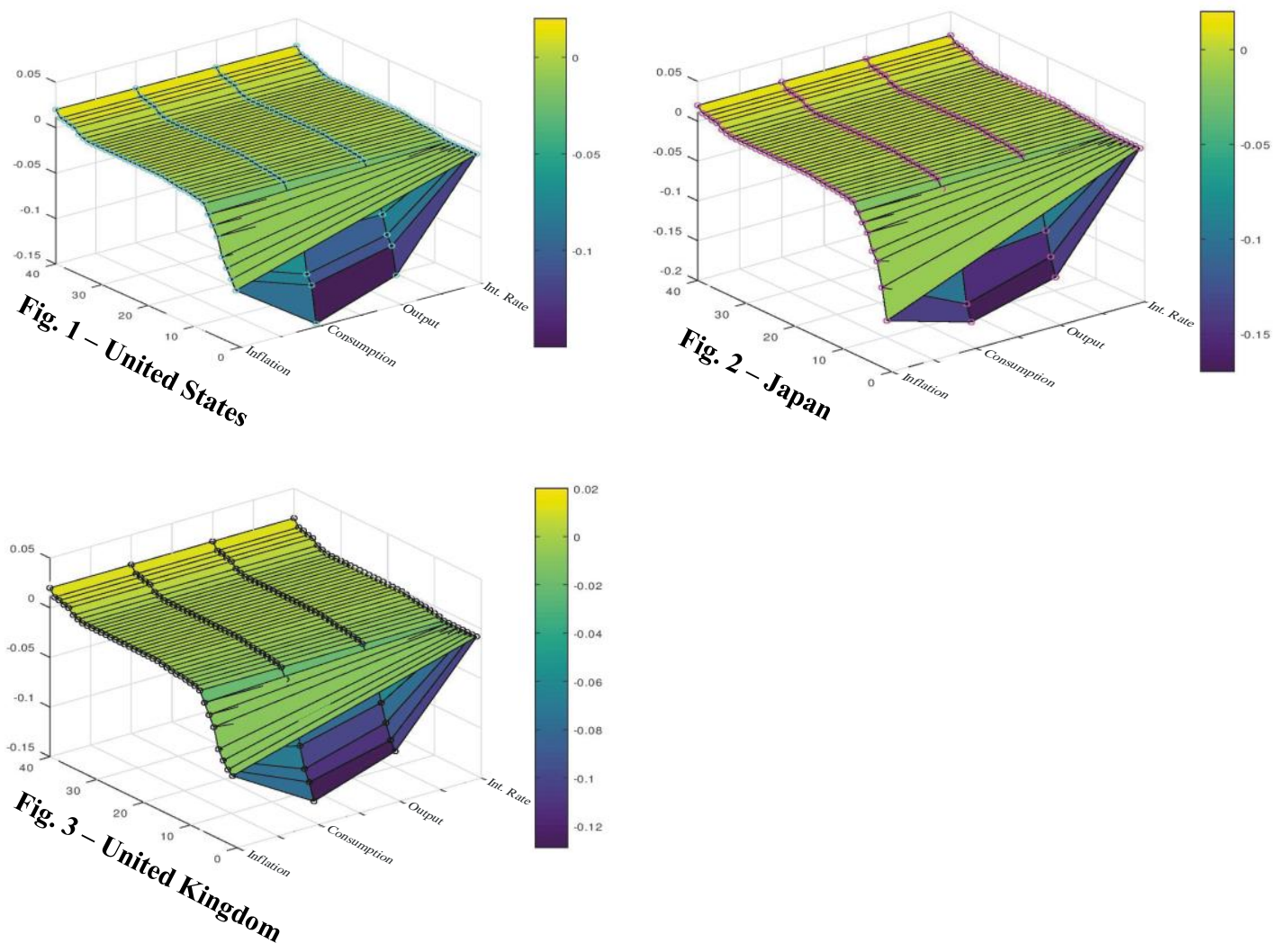

Panel 2 (Figs. 4-6) presents the result of a persistent fiscal policy in the central bank stabilisation objective such that monetary rule responds to both inflation and output gap. In this simulation scenario, the fiscal policy interacts with monetary policy for four periods. Thus, we observed that the dynamic responses of the macroeconomic predictors to the stochastic innovation in the model varied from the first simulation scenario. The US economy records initial deviations of $12 \%, 7.74 \%$ and $10.86 \%$ from steady states; Japan shows $14 \%, 11 \%$ and $12.6 \%$, while the UK estimates show $10.5 \%, 7 \%$ and $8.3 \%$ deviation from the equilibrium. By allowing the fiscal policy to persist in the stabilisation goal, the Federal Reserve was capable 
of reducing losses by $20 \%, 14 \%$ and $9.5 \%$; BOK by $17.64 \%, 20.86 \%$ and $11.88 \%$; BOE by $18.6 \%, 12.5 \%$ and $19.41 \%$ on consumption, inflation and output relative to the first case scenario. Although the previous findings (see Adam, 2011; Bhattarai, Trzeciakiewicz \& 2017; Blanchard, 2018; Blanchard, Erceg \& Lindé, 2015; Catalano \& Pezzolla, 2017; Christiano, Eichenbaum \& Trabandt, 2016; Falagiarda \& Saia, 2017; Farmer, Khramov \& Nicolò, 2015; Gelain et al., 2019; Gerke et al., 2013; Ginters \& Buss, 2015; Miyamoto et al., 2017; Nakamichi, 2012; Patrick et al., 2019; Ramey \& Zubairy, 2018; Reis, 2018; Woodford, 2007) vary across the multiplier effects of fiscal activities in the ZLB economic atmosphere, our findings support the fiscal policy potency in minimising shock effects on the macroeconomic predictors in the ZLB environment in the USA, Japan and the UK. This finding reverberates the report by Schabert and Bredemeier (2015).

Panel 2. Standard Monetary and Persistent Fiscal Policy Interaction
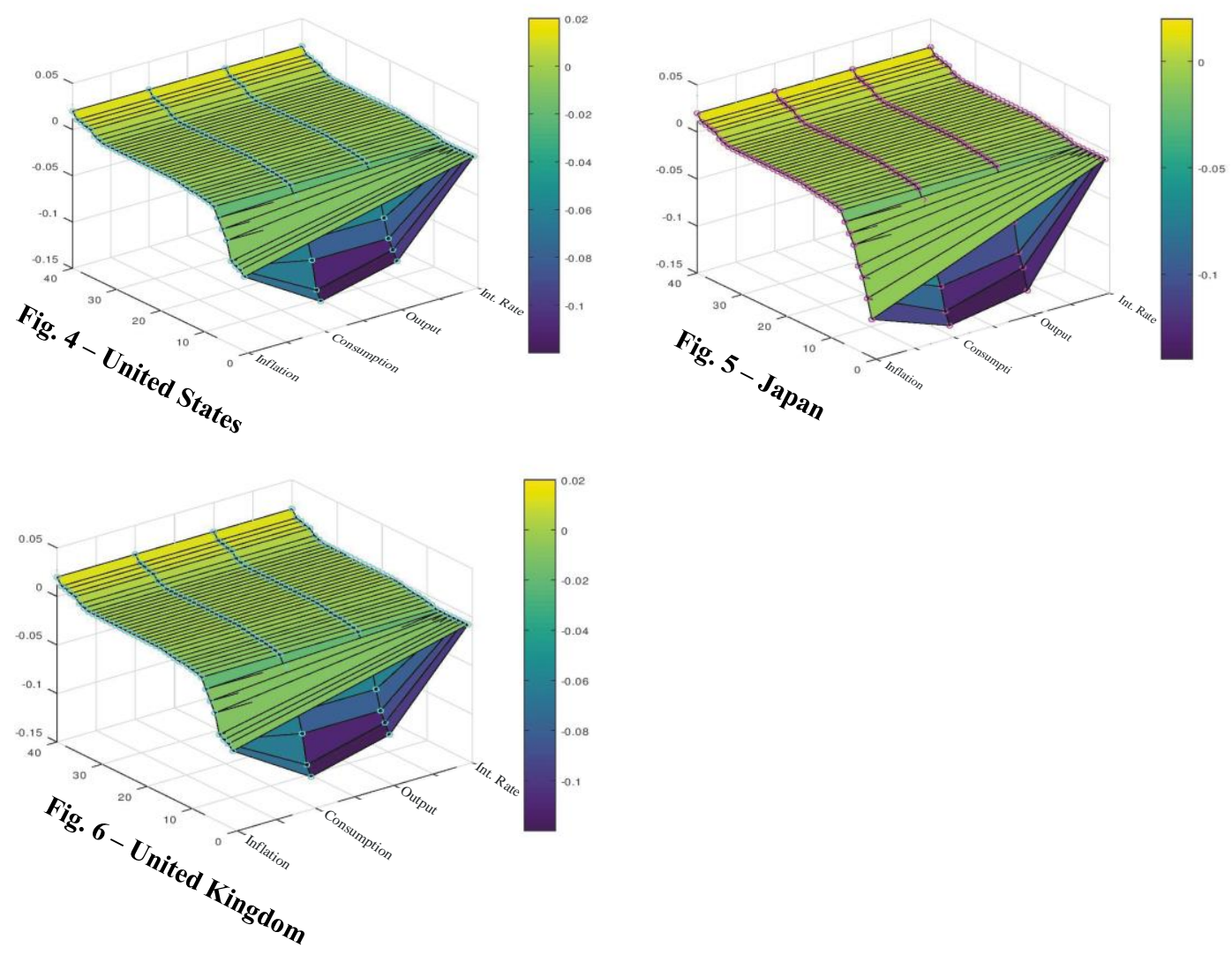

Panel 3 (Figures 7-9) simulates the one-time fiscal policy interaction with an exclusive inflation targeting monetary policy. In this case scenario, monetary reaction function responds only to inflationary pressure in their stabilization goal by allowing one-time fiscal policy response to address shock effects on macroeconomic predictors. We presumed that this scenario would worsen the shock effects on consumption, output and possibly inflation. Since output gap exerted pressure on 
inflation, the capacity of weak monetary policy, without fiscal support, to control the inflationary pressure might further be enfeebled. Our simulation confirmed that this scenario produced worse results relative to the above simulation results. The US data showed $16 \%, 12 \%$ and $13.5 \%$ consumption, inflation and output from the initial deviation from the equilibrium shocks. The Japanese estimation result recorded $19 \%$, $14.5 \%$ and $15.3 \%$ initial deviations and UK estimates showed $13 \%, 8.2 \%$ and $11.5 \%$ initial deviations of these macroeconomic predictors. This result implies that interacting fiscal policy with this monetary strategy is inefficient in any ZLB environment.

Panel 3. Exclusive Inflation Targeting Monetary and Low Fiscal Policy Interaction
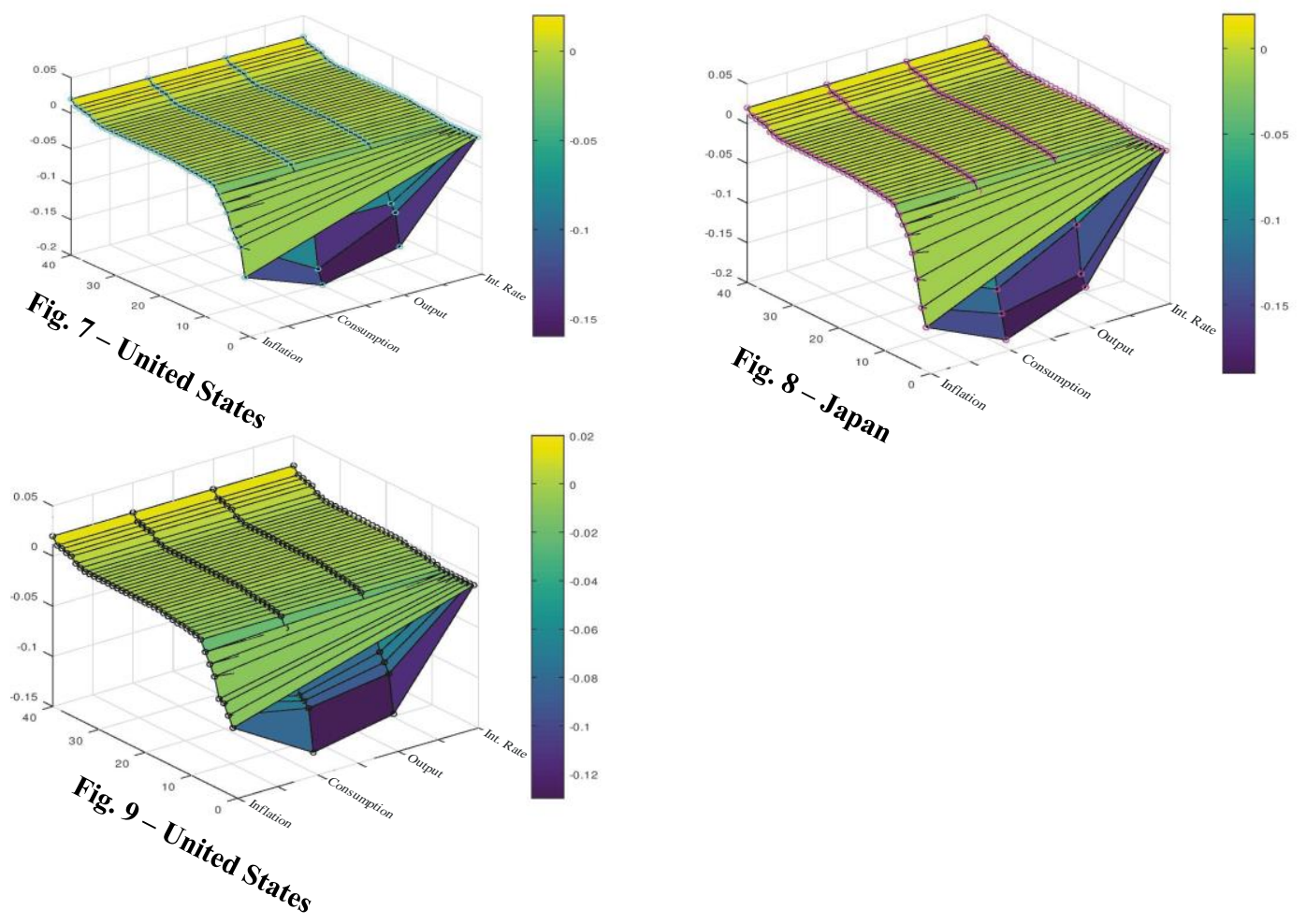
Panel 4 (Figs. 7-9) replicates the simulation procedure for the third panel but allowed the fiscal policy to persist. We observed improvement in the losses to consumption, inflation and output for solely inflation targeting monetary policy, which allowed for persistent interactive fiscal policy in the stabilisation strategy. The consumption, inflation and output initial losses to shock effect dropped to $15.5 \%$, $10 \%$ and $12.7 \%$ in the USA and showed percentage improvement of $3.13 \%$, $16.67 \%$ and $5.9 \%$ relative to the third simulation scenario. The Japanese result recorded $17.9 \%, 14.1 \%$ and $14.7 \%$ initial deviations and improved by $5.78 \%$, $2.7 \%$ and $3.9 \%$ relative to the third simulation. The UK estimates revealed $10.8 \%$, $7.5 \%$ and $8.4 \%$ initial deviations and improved by $16.9 \%, 8.5 \%$ and $27 \%$ relative to the third simulation scenario.

Panel 4. Exclusive Inflation Targeting and Persistent Fiscal Interaction
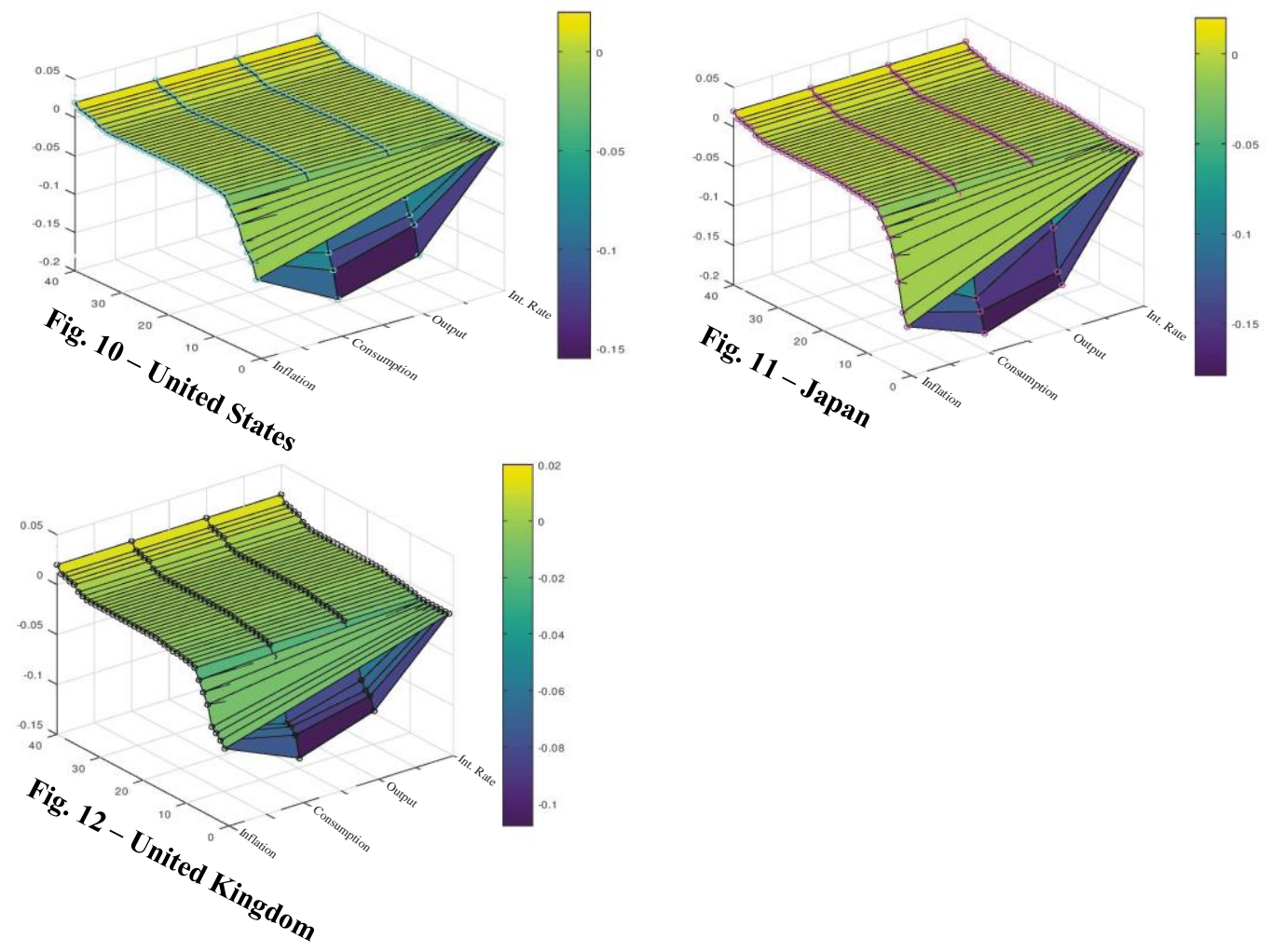

Our estimation supported the theory. First, we observed an optimal result when a comprehensive monetary policy was coordinated with a persistent interactive fiscal policy to achieve the stabilisation goals. Relatively, this $\left(S_{2}\right)$ produced the lowest losses to all the macroeconomic predictors in the zero lower bound environment during and after the shocks. Second, we observed that monetary policy rule that responded to both output and inflation improved the losses. Third, we noted that the contractionary fiscal policy tools such as high taxes-imposed constraints on the fiscal policy to fully mitigate losses from exogenous shocks. Thus, we present the posterior results for the optimal simulation in the section below. 


\section{Posterior Distribution}

Table 3 presents the posterior estimates for the optimal model. In this section, we compare and discuss the posterior means for the parameters across three economies.

Table 3. Posterior Estimation of the Optimal Calibrated Scenario $\left(\mathrm{S}_{2}\right)$ : High Fiscal Policy Involvement

\begin{tabular}{|c|c|c|c|c|c|c|c|c|}
\hline \multirow[t]{3}{*}{ Parameters } & & \multicolumn{7}{|c|}{ Prior } \\
\hline & & \multirow[b]{2}{*}{ Density } & \multicolumn{2}{|c|}{ United States } & \multicolumn{2}{|c|}{ Japan } & \multicolumn{2}{|c|}{ United Kingdom } \\
\hline & & & Mean & Std. & Mean & Std. & Mean & Std. \\
\hline Habit & $h$ & Beta & 0.92 & 0.01 & 0.67 & 0.05 & 0.79 & 0.01 \\
\hline Risk averseness & $\rho$ & Normal & 1.25 & 0.03 & 1.12 & 0.09 & 0.99 & 0.01 \\
\hline Index price & $I_{p}$ & Beta & 0.30 & 0.05 & 0.23 & 0.01 & 0.37 & 0.05 \\
\hline Index wage & $I_{\omega}$ & Beta & 0.43 & 0.05 & 0.36 & 0.03 & 0.56 & 0.08 \\
\hline Calvo price & $p$ & Beta & 0.87 & 0.02 & 0.81 & 0.04 & 0.95 & 0.02 \\
\hline Calvo wage & $\omega$ & Beta & 0.88 & 0.01 & 0.75 & 0.04 & 0.60 & 0.03 \\
\hline Mon.rule inflation & $m_{\pi}$ & Normal & 1.34 & 0.15 & 1.21 & 0.08 & 1.23 & 0.07 \\
\hline Mon.rule output gap & $m_{y}$ & - & - & - & - & - & - & - \\
\hline Interest smoothening & $m_{p}$ & Beta & 0.94 & 0.01 & 0.86 & 0.02 & 0.79 & 0.03 \\
\hline Capital share & $\alpha$ & Normal & 0.25 & 0.01 & 0.18 & 0.01 & 0.34 & 0.02 \\
\hline Bond spread & $\delta$ & Gamma & 0.42 & 0.06 & 0.24 & 0.02 & 0.19 & 0.01 \\
\hline AR(1) wage mark -up & $w_{1}$ & Beta & 0.84 & 0.01 & 0.93 & 0.01 & 0.75 & 0.01 \\
\hline AR(1) bond spread & $b_{1}$ & Beta & 0.86 & 0.02 & 0.49 & 0.01 & 0.82 & 0.01 \\
\hline AR(1) price mark- up & $\rho_{1}$ & Beta & 0.79 & 0.07 & 0.82 & 0.04 & 0.73 & 0.02 \\
\hline AR(1) technology & $\varphi_{1}$ & Beta & 0.86 & 0.04 & 0.76 & 0.02 & 0.89 & 0.01 \\
\hline AR(1) government & $g_{1}$ & Beta & 0.95 & 0.03 & 0.93 & 0.01 & 0.94 & 0.01 \\
\hline AR(1) tax shock & $\tau_{1}$ & Beta & 0.89 & 0.03 & 0.91 & 0.01 & 0.91 & 0.01 \\
\hline AR(1) monetary policy & $\psi_{1}$ & Beta & 0.19 & 0.01 & 0.12 & 0.02 & 0.11 & 0.02 \\
\hline Std. Dev wage mark -up & $w_{2}$ & Inv Gam. & 0.16 & 0.04 & 0.23 & 0.02 & 0.18 & 0.01 \\
\hline Std. Dev. bond spread & $b_{2}$ & Inv Gam. & 0.07 & 0.01 & 0.01 & 0.01 & 0.03 & 0.01 \\
\hline Std. Dev. price mark-up & $\rho_{2}$ & Inv Gam. & 0.25 & 0.08 & 0.12 & 0.01 & 0.32 & 0.03 \\
\hline Std. Dev. technology & $\varphi_{2}$ & Inv Gam. & 0.42 & 0.13 & 0.34 & 0.03 & 0.35 & 0.02 \\
\hline Std. Dev. government & $g_{2}$ & Inv Gam. & 0.34 & 0.01 & 0.56 & 0.02 & 0.54 & 0.05 \\
\hline Std. Dev. tax shock & $\tau_{2}$ & Inv Gam. & 1.21 & 0.02 & 1.26 & 0.02 & 1.43 & 0.08 \\
\hline Std. Dev. monetary rule & $\psi_{2}$ & Inv Gam. & 0.16 & 0.04 & 0.09 & 0.02 & 0.08 & 0.02 \\
\hline
\end{tabular}

Source: Researchers (2019).

Our estimation revealed that households possessed fair habits in the consumption function $h$ 's being 0.92, 0.67 and 0.79 for the USA, Japan and the UK, respectively, which were close to the results found in Bhattarai \& Trzeciakiewicz (2017), Drautzburg \& Uhlig (2015), Nasir et al. (2016). The risk averseness $\rho s$ was estimated $1.25,1.12$ and 0.95 . It was evaluated within the neighbourhoods of 1.17 by Drautzburg and Uhlig (2015) for the US data, 1.13 obtained by Iwata (2013) for the Japanese data, and 0.95 obtained by Bhattarai and Trzeciakiewicz (2017) for the UK data. The calvo sticky wage, $\omega$ 's was $0.88,0.75$ and 0.60 , which indicated that wage adjustment occurred approximately every fourth quarter in the USA, third quarter in Japan and the UK. The calvo sticky price parameters; $p$ 's were $0.87,0.81$ and 0.95 , which indicated that prices were marked up at approximately one year in the three economies, respectively. The interest rate smoothing estimates; $m_{p}$ were $0.94,0.86$ and 0.79 ; They were around the estimated interest rate persistence; 0.92 was obtained 
by Drautzburg and Uhlig (2015), 0.80 - by Iwata (2013) and 0.74 -by Bhattarai and Trzeciakiewicz (2017). The estimated monetary response to inflation $m_{\pi}$ was 1.34 , 1.21 and 1.23; this evidence showed a gradual weakness in the monetary policy control on inflation. We assumed that the ability of monetary policy could have been worse in the absence of a persistent interactive fiscal policy. Also, from the shocks to fiscal policy, our estimation demonstrates that shocks to government spending persisted than the tax shocks while monetary policy was at minimum across the economies.

\section{Variance Decomposition}

Table 4 summarises the variance decomposition we derived from the estimation. According to these estimates, shocks to fiscal policy and bond spread are the major drivers of the variations in the macroeconomic variables, while the mark-ups contribute less variations to these predictors in the United States. In Japan, the causes of variations are distributed across several shocks, but the result demonstrates lower effects from monetary policy and bond spread. We observed counter effects in the fiscal policy shocks in the United Kingdom That is, we observed positive shock from the expansionary government spending and a negative tax shock on consumption, output and inflation. The shock to mark-ups also relatively contributes to the variation in these macroeconomic predictors in the UK.

Table 4. Variance Decom. of the Optimal Calibrated Scenario $\left(\mathrm{S}_{2}\right)$ :

High Fiscal Policy Involvement

\begin{tabular}{|l|c|c|c|c|c|c|c|c|c|}
\hline & \multicolumn{3}{|c|}{ Inflation } & \multicolumn{3}{c|}{ Consumption } & \multicolumn{3}{c|}{ Output } \\
\hline Shocks & US & Japan & UK & US & Japan & UK & US & Japan & UK \\
\hline Wage mark-up & 4.02 & 17.34 & 11.07 & 8.03 & 15.93 & 14.3 & 4.58 & 13.25 & 9.13 \\
\hline Price mark-up & 7.5 & 16.03 & 13.9 & 6.63 & 19.83 & 9.34 & 4.04 & 16.84 & 12.01 \\
\hline Technology & 11.03 & 17.72 & 9.02 & 18.02 & 16.6 & 7.08 & 14.2 & 14.53 & 8.5 \\
\hline Government & 20.61 & 19.03 & 23.09 & 24.89 & 20.61 & 20.02 & 19.08 & 21.7 & 26.6 \\
\hline Bond spread & 20.23 & 5.03 & 6.01 & 19.45 & 6.32 & 8.60 & 20.02 & 9.29 & 10.21 \\
\hline Tax & 20.59 & 15.05 & 30.03 & 9.01 & 12.97 & 36.8 & 29.01 & 15.8 & 35.02 \\
\hline Monetary rule & 10.02 & 9.8 & 6.88 & 12.97 & 7.74 & 3.86 & 10.07 & 8.59 & 5.52 \\
\hline & & & & & & & & & \\
\hline \% Sum & 100 & 100 & 100 & 100 & 100 & 100 & 100 & 100 & 100 \\
\hline
\end{tabular}

US- United States, UK- United Kingdom

Source: Researchers (2019).

Table 5. Initial Macroeconomic Loss from Shocks

\begin{tabular}{|l|c|c|c|}
\hline Scenario & \multicolumn{3}{|c|}{ United States } \\
\hline & Inflation & Consumption & Output \\
\hline $\mathrm{S}_{1}$ & $9 \%$ & $15 \%$ & $12 \%$ \\
\hline $\mathrm{S}_{2}$ & $7.74 \%$ & $12 \%$ & $10.86 \%$ \\
\hline $\mathrm{S}_{3}$ & $12 \%$ & $16 \%$ & $13.5 \%$ \\
\hline $\mathrm{S}_{4}$ & $10 \%$ & $15.5 \%$, & $12.7 \%$ \\
\hline
\end{tabular}

Source: Researchers (2019). 


\section{CONCLUDING REMARKS}

The goal of the study was to describe the ability of the fiscal policy to absorb exogenous shocks from the nominal interest rate within the new Keynesian DSGE model in the USA, UK and Japan economies. Our theoretical intuition and empirical strategy followed the New Keynesian DSGE model proposed by Lorenzoni and Werning (2013), Werning (2015) and Cochrane (2017, 2018). Contrary to earlier studies, the findings of our simulations were robust to a number of checks. First, our simulation results suggested that the nominal interest rate limited the ability of monetary policy to respond to macroeconomic turbulence, particularly, when the economies had bias to preserve the interest rate at a lower bound period. Surprisingly, the results indicated that the fiscal expansionary stance acted as a shock absorber by compelling the macroeconomic predictors back to their initial equilibrium. However, fiscal discipline must be embraced to sustain this stability strategy. Contrariwise, we found shocks being transmitted from the contractionary fiscal policy with consequence on the economies that had bias to stimulate aggregate demand.

Comparably, specific country evidences showed mixed results. This was expected since these economies had different macroeconomic dynamics as well as varied policy prospect. For instance, in the United States, we observed bubble persistence in the interest rate, which helped manage irregular inflation, even though the monetary policy was inactive during the period observed. However, complementary expansionary fiscal stance and unconventional monetary approach were observed from our results.

In the United Kingdom, our estimated model showed an unevenly spread from two major sources, which was beyond the purview of the monetary policy control. First, we observed shock from the tax system practice on consumption and investment, which contrasted aggregate demand components. Second, the shocks from the nominal interest rate continued to drop the rate of investment. However, the UK economy continued to survive this paraded shock due to the active fiscal expansionary stance. Nevertheless, serious erosion in tax practice hampered the ability of agents' responses to aggregate demand as the economy continued to be exposed to exogenous shock. The UK tax system utilises a combination of income, capital and consumption in its tax base, which formed the overall tax objectives. The present taxes are inefficient and ineffective with adverse effects on consumption and output. The aftermath effect was observed in the unstable investment. This served as a signal to investors to postpone or delay investment and led to slower economic growth.

In Japan, the expansionary fiscal persistent stance continued to act as a stabilising mechanism to the economy. Specifically, the Japanese economy enjoyed an increase in consumption with exception of the perceived crowding-out private investment in some relative quarter during the zero lower bound rate period. While fiscal policy remained active, monetary policy struggled to normalize the macroeconomic turmoil in the economy. Thus, the present policy mix adopted in the Japanese economy needed to adopt the unconventional monetary policy to complement the current fiscal response that was found to be effective for managing the economy. 
This research thus supported the findings of Bhattarai \& Trzeciakiewicz (2017), Buera \& Nicolini (2014), Cochrane (2017, 2018), Lorenzoni \& Werning (2013), Miyamoto et al. (2017), Werning (2015) who had earlier advocated the need for the use of the fiscal policy to manage macroeconomic imbalance.

Finally, additional studies can complement this existing effort by investigating the role of global predictor during the zero lower bound period when the economies bias towards the adoption of persistence fiscal policy as a strategy for correcting macroeconomics imbalance.

\section{REFERENCES}

Abel, A. B. (1975). A Comparison of three Control Algorithms Applied to Monetarist-Fiscal Debate. Annal of Economic and Social Measurement, 1(3), 259-290.

Adam, K. (2011). Government Debt and Optimal Monetary and Fiscal Policy. European Economic Review, 55(1), 57-74. https://doi.org/10.1016/j.euroecorev.2010.11.003

Afonso, A., \& Jalles, J. T. (2017). Fiscal Episodes and Market Power. Open Economies Review, 28(2), 233-250. https://doi.org/10.1007/s11079-016-9419-7

Ashihara, A., \& Kameda, K. (2018). Is Fiscal Expansion More Effective in a Financial Crisis? Applied Economics Letters, 25(2), 111-114. https://doi.org/10.1080/13504851.2017.1299098

Azariadis, C. (2018). Riddles and Models: A Review Essay on Michel De Vroey's A History of Macroeconomics from Keynes to Lucas and Beyond. Journal of Economic Literature, 56(4), 1538-1576. https://doi.org/10.1257/jel.20181439

Barro, R. J. (1980). A Capital Market in an Equilibrium Business Cycle Model. Econometrica, 48(6), 1393. https://doi.org/10.2307/1912814

Barro, R. J. (1981). Output Effects of Government Purchases. Journal of Political Economy, 89(6), 1086-1120. https://doi.org/10.1086/261024

Barro, R. J., \& Gordon, D. B. (1983). Rules, Discretion and Reputation in a Model of Moneatry Policy. NBER Working Paper 1079. https://doi.org/10.3386/w1079

Baxter, B. M., \& King, R. G. (1993). Fiscal Policy in General Equilibrium. The American Economic Review, 83(3), 315-334.

Benchimol, J. (2015). Money in the Production Function: A New Keynesian DSGE Perspective. Southern Economic Journal, 82(1), 152-184. https://doi.org/10.2139/ssrn.2328135

Bhattarai, K., \& Trzeciakiewicz, D. (2017). Macroeconomic Impacts of Fiscal Policy Shocks in the UK: A DSGE analysis. Economic Modelling, 61, 321-338. https://doi.org/10.1016/j.econmod.2016.10.012

Blanchard, O. (2018). On the Future of Macroeconomic Models. Oxford Review of Economic Policy, 34(1-2), 43-54. https://doi.org/10.1093/oxrep/grx045

Blanchard, O. J., Erceg, C. J., \& Lindé, J. (2015). Jump-Starting the Euro Area Recovery: Would a Rise in Core Fiscal Spending Help the Periphery? Riksbank Research Paper Series No. 128. https://doi.org/10.2139/ssrn.2635382

Boldrin, B. M., Christiano, L. J., \& Fisher, J. D. M. (2001). Habit Persistence, Asset Returns , and the Business Cycle. The American Economic Review, 91(1), 149-166. https://doi.org/10.1257/aer.91.1.149

Boubaker, S., Nguyen, D. K., \& Paltalidis, N. (2018). Fiscal Policy Interventions at the Zero Lower Bound. Journal of Economic Dynamics and Control, 93, 297-314. https://doi.org/10.1016/j.jedc.2018.01.048

Buera, F., \& Nicolini, J. P. (2014). Liquidity Traps and Monetary Policy: Managing a Credit Crunch. FRB of Chicago Working Paper No. 2014-14. https://doi.org/10.2139/ssrn.2537452

Calvo, G. A. (1983). Staggered Prices in a Utility-Maximizing Framework. Journal of Monetary Economics, 12(3), 383-398. https://doi.org/10.1016/0304-3932(83)90060-0

Cars, H., \& Lustenhouwer, J. (2017). Managing Unanchored, Heterogeneous Expectations and Liquidity Traps. BERG Working Paper Series, No. 131, Bamberg University, Bamberg Economic Research Group (BERG), Bamberg, 1-44.

Catalano, M., \& Pezzolla, E. (2017). The Italian Labor Market Reform : An Evaluation of the Jobs Act Using the Prometeia DSGE Model. Italian Economic Journal, 3(2), 209-238. https://doi.org/10.1007/s40797017-0057-z

Christiano, L., Eichenbaum, M., \& Rebelo, S., (2011). When Is the Government Spending Multiplier Large? Journal of Political Economy, 119(1), 78-121. https://doi.org/10.1086/659312

Christiano, L. J., Eichenbaum, M. S., \& Trabandt, M. (2016). Unemployment and Business Cycles. Econometrica, 84(4), 1523-1569. https://doi.org/10.3982/ECTA11776

Christiano, L. J., Eichenbaum, M. S., \& Trabandt, M. (2018). On DSGE Models. Journal of Economic 
Perspectives, 32(3), 113-140. https://doi.org/10.1257/jep.32.3.113

Christiano, L. J., Trabandt, M., \& Walentin, K. (2011). DSGE Models for Monetary Policy Analysis. Handbook of Monetary Economics, 3, 285-367. https://doi.org/10.1016/B978-0-444-53238-1.00007-7

Clarida, R., Gali, J., \& Gertler, M. (1998). Monetary Policy Rules and Macroeconomic Stability: Evidence and Some Theory. National Bureau of Economic Research Working Paper 6442. https://doi.org/10.3386/w6442

Cochrane, J. H. (2005). Money as Stock. Journal of Monetary Economics, 52(3), 501-528. https://doi.org/10.1016/j.jmoneco.2004.07.004

Cochrane, J. H. (2011). Determinacy and Identification with Taylor Rules. Journal of Political Economy, 119(3), 565-610. https://doi.org/10.1086/660817

Cochrane, J. H. (2014). Monetary Policy with Interest on Reserves. Journal of Economic Dynamics and Control, 49, 74-108. https://doi.org/10.1016/j.jedc.2014.09.003

Cochrane, J. H. (2017). The New-Keynesian Liquidity Trap. Journal of Monetary Economics, 92, 47-63. https://doi.org/10.1016/j.jmoneco.2017.09.003

Cochrane, J. H. (2018). Stepping on a Rake: The Fiscal Theory of Monetary Policy. European Economic Review, 101, 354-375. https://doi.org/10.1016/j.euroecorev.2017.10.011

Diniz, A. (2018). Effects of Fiscal Consolidations in Latin America. IMF Economic Review, 66(4), 694-731. https://doi.org/10.1057/s41308-018-0069-1

Drautzburg, T., \& Uhlig, H. (2015). Fiscal Stimulus and Distortionary Taxation. Review of Economic Dynamics, 18(4), 894-920. https://doi.org/10.1016/j.red.2015.09.003

Falagiarda, M., \& Saia, A. (2017). Credit, Endogenous Collateral and Risky Assets: A DSGE Model. International Review of Economics and Finance, 49, 125-148. https://doi.org/10.1016/j.iref.2017.01.025

Farmer, R. E. A., Khramov, V., \& Nicolò, G. (2015). Solving and estimating Indeterminate DSGE Models. Journal of Economic Dynamics and Control, 54, 17-36. https://doi.org/10.1016/j.jedc.2015.02.012

Förster, B., \& Hayo, B. (2018). Monetary and Fiscal Policy in Times of Crisis: A New Keynesian Perspective in Continuous Time. Manchester School, 86(1), 21-48. https://doi.org/10.1111/manc.12173

Gelain, P., Iskrev, N., Lansing, K. J., \& Mendicino, C. (2019). Inflation Dynamics and Adaptive Expectations in an Estimated DSGE Model. Journal of Macroeconomics, 59, 258-277. https://doi.org/10.1016/j.jmacro.2018.12.002

Gerke, R., Jonsson, M., Kliem, M., Kolasa, M., Lafourcade, P., Locarno, A., Makarski, K., McAdam, P. (2013). Assessing Macro-Financial Linkages: A Model Comparison Exercise. Economic Modelling, 31, 253-264. https://doi.org/10.1016/j.econmod.2012.10.019

Buss, G. (2015). Financial Frictions in a DSGE Model for Latvia. Dynare Working Papers Series, Working paper No. 42.

Gobbi, A., \& Grazzini, J. (2019). A Basic New Keynesian DSGE Model With Dispersed Information: An Agent-Based Approach. Journal of Economic Behavior and Organization, 157, 101-116. https://doi.org/10.1016/j.jebo.2017.12.015

Hur, J., \& Rhee, W. (2019). Multipliers of Expected vs Unexpected Fiscal Shocks: The Case of Korea. Economic Modelling, (3 June 2019). https://doi.org/10.1016/j.econmod.2019.05.021

Iwata, Y. (2009). Fiscal Policy in an Estimated DSGE Model of the Japanese Economy: Do Non-Ricardian Households Explain All? Social ESRI Discussion PaperResearch, (216), 2-33. Retrieved from http://www.esri.go.jp/jp/archive/e_dis/e_dis220/e_dis216a.pdf

Iwata, Y. (2013). Two fiscal Policy Puzzles Revisited: New Evidence and an Explanation. Journal of International Money and Finance, 33, 188-207. https://doi.org/10.1016/j.jimonfin.2012.11.015

Jiang, W. (2019). Optimal Taxation Under Equilibrium Unemployment and Economic Profits. The B.E. Journal of Macroeconomics, 19(1), 1-21. https://doi.org/10.1515/bejm-2017-0226

Jump, R. C., \& Levine, P. (2019). Behavioural New Keynesian Models. Journal of Macroeconomics, 59, 59-77. https://doi.org/10.1016/j.jmacro.2018.11.002

Kataryniuk, I., \& Vallés, J. (2018). Fiscal Consolidation after the Great Recession: The Role of Composition. Oxford Economic Papers, 70(2), 563-585. https://doi.org/10.1093/oep/gpx032

Lorenzoni, G., \& Werning, I. (2013). Slow Moving Debt Crises. NBER Working Paper No. 19228, 1-32. https://doi.org/10.3386/w19228

Mankiw, N. G., \& Reis, R. (2018). Friedman's Presidential Address in the Evolution of Macroeconomic Thought. Journal of Economic Perspectives, 32(1), 81-96. https://doi.org/10.1257/jep.32.1.81

Miyamoto, W., Nguyen, T. L., \& Sergeyev, D. (2016). Government Spending Multipliers Under the Zero Lower Bound : Evidence from Japan (October 29, 2016). Available: https://doi.org/10.2139/ssrn.2865510

Nakamichi, T. (2012). Decisive Monetary Easing Policy to Beat Deflation. Bank of Japan; NAICS: 521110, Don Jones Institutional News, 22, Oct 2012.

Nasir, M. A., Yago, M., Soliman, A. M., \& Wu, J. (2016). Financial stability, wealth effects and Optimal Macroeconomic Policy Combination in the United Kingdom: A New-Keynesian Dynamic Stochastic General Equilibrium Framework. Cogent Economics \& Finance, 4, 1-25. https://doi.org/10.1080/23322039.2015.1136098 
Patrick, F., Moura, A., \& Pierrard, O. (2019). Shadow Banking and Financial Regulation : A Small-Scale DSGE Perspective. Journal of Economic Dynamics and Control, 101, 130-144. https://doi.org/10.1016/j.jedc.2019.02.001

Praščević, A., \& Ješić, M. (2019). Modeling Macroeconomic Policymakers' Interactions under Zero Lower Bound Environment: The New Keynesian Theoretical Approach. Journal of Central Banking Theory and Practice, 8(1), 5-38. https://doi.org/10.2478/jcbtp-2019-0001

Prota, F., \& Grisorio, M. J. (2018). Public Expenditure in time of Crisis: are Italian Policymakers Choosing the Right Mix? Economia Politica, 35(2), 337-365. https://doi.org/10.1007/s40888-018-0124-4

Ramey, V. A. (2011). Can Government Purchases Stimulate the Economy? Journal of Economic Literature, 49(3), 673-685. https://doi.org/10.1257/jel.49.3.673

Ramey, V. A., \& Zubairy, S. (2018). Government Spending Multipliers in Good Times and in Bad : Evidence from US Historical Data. Journal of Political Economy, 126(2), 850-897. https://doi.org/10.1086/696277

Reis, R. (2018). Is something really wrong with macroeconomics? Oxford Review of Economic Policy, 34(1-2), 132-155. https://doi.org/10.1093/oxrep/grx053

Roch, F., \& Uhlig, H. (2018). The Dynamics of Sovereign Debt Crises and Bailouts. Journal of International Economics, 114, 1-13. https://doi.org/10.1016/j.jinteco.2018.05.002

Schabert, A., \& Bredemeier, C. (2015). Fiscal Policy, Interest Rate Spreads, and the Zero Lower Bound. Department of Economics University of Cologne Albertus-Magnus-Platz, D-50923 Köln, Germany, Working Paper Series, No. 80.

Shobande, O. (2019). Monetary Policy Spillover through Industrial Growth in Nigeria: A Time Series Analysis. Economics and Business, 33(1), 94-110. https://doi.org/10.2478/eb-2019-0007

Shobande, O. A. (2018). Modelling the Dynamics of Government Finance on Bond Market Return in Nigeria. Theoretical Economics Letters, 8, 3438-3443. https://doi.org/10.4236/tel.2018.815210

Uhlig, H. (2005). What are the Effects of Monetary Policy on Output? Results from an Agnostic Identification Procedure. Journal of Monetary Economics, 52(2), 381-419. https://doi.org/10.1016/j.jmoneco.2004.05.007

Vines, D., \& Wills, S. (2018). The Rebuilding Macroeconomic Theory Project: An Analytical Assessment. Oxford Review of Economic Policy, 34(1-2), 1-42. https://doi.org/10.1093/oxrep/grx062

Werning, I. (2015). Managing a Liquidity Trap. NBER Working Paper Series, 67(6), 14-21.

Woodford, M. (2007). Forecast Targeting as a Monetary Policy Strategy: Policy Rules in Practice. NBER Working paper 13716. https://doi.org/10.3386/w13716

\section{AUTHORS' SHORT BIOGRAPHIES}

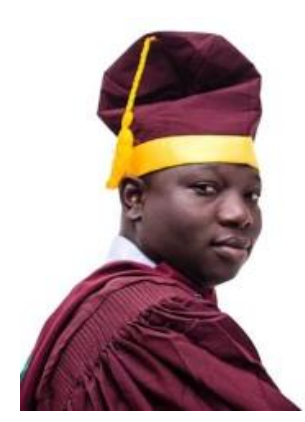

Olatunji Abdul Shobande is a Ph.D. researcher in economics at the University of Aberdeen, the UK. His research expertise is macroeconomics, energy economics, health economics and financial econometrics. His research has appeared in the leading academic journals, such as the Review of Economies, Review of Urban \& Regional Studies, Science of Total Environment, Business and Economics.

E-mail: o.shobande.19@abdn.ac.uk

ORCID ID: https://orcid.org/0000-0003-4528-1857

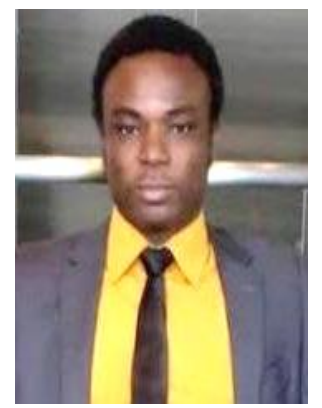

Shodipe Oladimeji Tomiwa is a passionate researcher and has won multiple awards for creative research. Oladimeji specialises in macroeconomics and international monetary research and envisions the best solutions through econometric modelling.

E-mail: otshodipe@eiu.edu 